Saint Louis University School of Law

Scholarship Commons

All Faculty Scholarship

2004

Seeking Consistency in Relating Capital to Current Expenditures

Henry Ordower

Follow this and additional works at: https://scholarship.law.slu.edu/faculty

Part of the Tax Law Commons 


\section{S A I N T L O U IS}

U N N I V V E

SCHOOL OF LAW

\section{SAINT LOUIS UNIVERSITY SCHOOL OF LAW \\ Legal Studies Research Paper Series}

No. 04-01

2004

Seeking Consistency in Relating Capital to Current Expenditures

Henry Ordower

Saint Louis University School of Law 


\title{
Seeking Consistency in Relating Capital to Current Expenditures*
}

\author{
by \\ Henry Ordower*
}

\section{Introduction: Separating Personal from Income-Producing Worlds and Current from Capital Expenditures.}

The court in Gilmore v. United States ${ }^{1}$ permitted the taxpayer to capitalize his litigation expenditures to the corporate shares he sought to protect. Although consistent with a line of decisions holding that taxpayers must capitalize, ${ }^{2}$ rather than deduct as ordinary and necessary business expenses ${ }^{3}$ or expenses of income production, ${ }^{4}$ the

\footnotetext{
* Copyright $(2004$ Henry Ordower

** Professor of Law, Saint Louis University School of Law, A.B. Washington University, M.A., J.D. The University of Chicago.

${ }^{1} 245$ F. Supp. 383 (N.D. Cal. 1965)

${ }^{2}$ Under current law section 263 of the Internal Revenue Code of 1986, as amended (the "Code"). This article refers to specific sections of the code as "I.R.C. §" followed by a section number. Capitalization of an expenditure results in an increase in the taxpayer's adjusted basis in the property, I.R.C. $\S 1011$, and will impact the amount of the taxpayer's gain or loss from disposition of the property (and, in the case of depreciable property under I.R.C. $\S 167$, may increase the taxpayer's allowance for depreciation). For ease of understanding, this article refers to current provisions of the Code, rather than the provisions of Internal Revenue Code in effect at the time some of the cases the article cites were decided unless the earlier provision differed from the current law in a way that might affect the outcome of the case.

${ }^{3}$ I.R.C. $§ 162$.
} 
litigation expenditures they incur in defending their title to the property, the decision is troubling because it confuses a taxpayer's income producing and personal tax worlds. The ruling followed remand from the Supreme Court ${ }^{5}$ where the taxpayer argued deductibility of the expenditures and lost, not because the litigation expenditures were capital expenditures, although that also may have been true, but because the expenditures were personal. ${ }^{6}$ The Supreme Court rejected the taxpayer's argument that he defended the suit for divorce only to protect his corporate ownership, and not to resist dissolution of the marriage, so that the expenditures were deductible in his trade or business. ${ }^{7}$ The Court held that the origin and nature of the claim controlled the tax characterization of the expenditures. Dissolution of marriage was a family and personal matter unrelated to income production or taxpayer's trade or business. Accordingly, the taxpayer could not deduct expenses incurred in defense of a claim for dissolution regardless of the taxpayer's motivation for defending. ${ }^{8}$ Nevertheless, on remand, the district court permitted the taxpayer to increase his basis in the shares he had sought to protect by the amount of the litigation expenditures. The shares related to his trade or business and his income producing activities.

\footnotetext{
${ }^{4}$ I.R.C. $§ 212$.

${ }^{5}$ United States v. Gilmore, 372 U.S. 39; 83 S. Ct. 623; 9 L. Ed. 2d 570 (1963).

${ }^{6}$ With limited and express exceptions, I.R.C. $§ 262$ denies deductions for “personal, living, or family expenses."

${ }^{7}$ I.R.C. $§ 162$.

${ }^{8}$ U.S. v. Gilmore, 372 U.S. at 629.
} 
The lower court's decision in Gilmore ${ }^{9}$ blurred the contrast between the taxpayer's personal and income producing tax worlds. An individual's tax world divides into two functionally discrete worlds, a personal world and an income-producing world. Generally, in the income-producing world, expenditures ${ }^{10}$ that do not produce, increase the value of, or extend the useful life of durable property are deductible ${ }^{11}$ and, in the personal world, such expenditures are not deductible. ${ }^{12}$ While the tax law's assignment of expenditures to the personal world, rather than the income-producing world, may be somewhat arbitrary, ${ }^{13}$ once assigned, the rule of non-deductibility applies unless Congress expressly chooses to provide a deduction for other policy reasons. ${ }^{14}$ By the same token, once an expenditure that does not produce property is assigned to the income-producing world, it is deductible unless Congress expressly chooses to limit its

\footnotetext{
${ }^{9}$ Gilmore v. U.S., supra note 1.

${ }^{10}$ This article will use the term "expenditure" to refer to both cash payments, allowances such as depreciation and the monetary value of services.

${ }^{11}$ I.R.C. $\$ \S 162$ and 212 . Both the cited provisions require that the expenditure be ordinary or current and necessary or appropriate to the income-producing activity.

${ }^{12}$ I.R.C. $\$ 262$.

${ }^{13}$ For example, commuting expenses are personal because the taxpayer could have chosen to live where he or she would not have to commute. Treas. reg. § 1.162-2(e), 1.262-1(b)(5). Germany assigns commuting expenses to the income producing world and permits a deduction for commuting expenses.

Einkommensteuergesetz (Income Tax Law) $§ 9$ (1) 4.

${ }^{14}$ Examples include charitable contributions deductible under I.R.C. §170, catastrophic medical expenses under I.R.C. $\S 213$ to the extent they exceed, in the aggregate, $7.5 \%$ of the taxpayer's adjusted gross income similarly deductible, catastrophic casualty losses deductible under I.R.C. §165(c), (h).
} 
deductibility ${ }^{15}$ or to make it non-deductible for other policy reasons. ${ }^{16}$ Similarly, with limited exceptions, losses in the personal world are not deductible, but in the incomeproducing world losses are deductible. ${ }^{17}$ Gains in both worlds generally are taxable. ${ }^{18}$

${ }^{15}$ For example, I.R.C. $\$ 67$ limits as miscellaneous itemized deductions deductibility of many expenses of income production.

${ }^{16}$ For example, I.R.C. $\$ 280 \mathrm{E}$ that denies a deduction for expenses of the illegal sale of drugs. This latter provision is exceptional, as the federal income tax law generally draws no distinction between the conduct of legal and illegal trades or businesses with respect to ordinary and necessary business expenses. Commissioner v. Tellier, 383 U.S. 687 (1966) (allowing deduction for the unsuccessful defense of a criminal prosecution for securities fraud - conviction meaning the activity was illegal). And Commissioner v. Sullivan, 356 U.S. 27 (1958) (allowing deductions for rent and wages paid by operators of a gambling enterprise when the specific rent and wage payments were illegal under state law, lest the business be taxed on its gross revenue). Compare, Tank Truck Rentals, Inc. v. Commissioner, 356 U.S. 30 (1958) (holding fines for operating trucks weighing in excess of the state weight limit not deductible because the deduction might undercut the impact of the state sanction). The Sullivan analysis may have lost its vitality following enactment of I.R.C. $\S 162(\mathrm{c})(2)$ that disallows deductions for illegal payments under a state law that is generally enforced would render almost all expenses of most illegal businesses non-deductible, but, if so, I.R.C. $\S 280$ E should not have necessary to deny the deduction for expenses of drug dealers. For an argument for repeal of I.R.C. §280E, see Note (Carrie F. Keller), The Implications of I.R.C. §280E In Denying Ordinary and Necessary Business Expense Deductions to Drug Traffickers, 47 ST. L. U. L. J. 157 (2003).

${ }^{17}$ I.R.C. $\$ 165(\mathrm{c})$. As a limitation on deductibility of losses in the income producing world, the tax law treats recognized losses from the sale or exchange of capital assets less favorably than other losses by limiting their deductibility under I.R.C. $§ 1211$.

${ }^{18}$ I.R.C. $\S \S 61(a)(3), 1001(c)$. 
Expenditures, once made, do not move from income-producing to personal or vice versa. It may be difficult to classify the expenditure as personal or income producing. For example, clothing that is different from what the taxpayer customarily wears has been the subject of litigation a number of times. A new lawyer operating as a sole proprietor in the practice of law buys business suits for daily office wear. Although the lawyer wears jeans and t-shirts at all other times, the cost of the suits is a personal expense, not a capital expenditure or an expense of income-production. ${ }^{19}$

However, if the expenditures produce or enhance property - that is, they are capital expenditures - the property, so produced or enhanced, may move from the taxpayers income-producing to personal world or vice versa, even though the expenditure itself may not move. For example, the taxpayer pays an architect to design a new kitchen for her personal residence. The architect's fee becomes part of cost of the new kitchen, a capital expenditure that becomes part of the basis of property the taxpayer holds in the personal world. The taxpayer may not capitalize the architect's fee to property the taxpayer holds in her trade or business even though the taxpayer might contend that she installed the new kitchen only to impress her business clients and thereby enhance her status in the business world. ${ }^{20}$ The fee increases the taxpayer's adjusted basis in the kitchen (and house), ${ }^{21}$ and the taxpayer may recover the cost, for tax purposes, upon sale

\footnotetext{
${ }^{19}$ Pevsner v. Commissioner, 628 F.2d $467\left(5^{\text {th }}\right.$ Cir. 1980) (taxpayer, an employee of the Yves St. Laurent clothing store bought that brand to wear at work, but customarily did not dress in that style, could not deduct the cost of the clothing because the clothes were usable for general wear in her community).

${ }^{20}$ Perhaps she will make the kitchen a subject for the small talk that accompanies business discussions.

${ }^{21}$ I.R.C. $\$ 1016(\mathrm{a})(1)$.
} 
of the house at a gain ${ }^{22}$ but may not deduct loss on the sale. ${ }^{23}$ If the taxpayer chooses not to use the architect's plans, she abandons the plans and may not deduct her loss. ${ }^{24}$ On the other hand, if later, the taxpayer uses the plans, builds the kitchen, and converts the house into a bed and breakfast residence for tourists, the house and kitchen, including the cost of the architect's plans, become income-producing property at the time of conversion. So long as the value of the house and kitchen equal or exceed the taxpayer's adjusted basis at the time of conversion, ${ }^{25}$ the adjusted basis of the house and kitchen will generate a depreciation allowance each year. ${ }^{26}$

\footnotetext{
${ }^{22}$ I.R.C. $\S \S 1001,1011$.

${ }^{23}$ I.R.C. $\$ 165(c)$.

${ }^{24} I d$. Abandonment of the plans is a loss in the personal world.

${ }^{25}$ Loss in value occurring before the conversion to income producing property diminishes the adjusted basis available for depreciation allowances after conversion because losses in the personal world are not deductible. Treas. reg. $\S 1.167(\mathrm{~g})-1$.

${ }^{26}$ I.R.C. $\$ 168$ measures and allows the deduction for depreciation under $§ 167$ applicable to tangible property.
} 
The decision in the Gilmore remand ${ }^{27}$ and the decision in Welch v. Helvering ${ }^{28}$ might lead the taxpayer to a different conclusion concerning expenditure movement from personal to income producing worlds. Based upon those decisions, the taxpayer might accept that she must capitalize the architect's fee, but she will add it to her basis in depreciable business property. And the taxpayer who purchased the suits may argue that, even though personal in nature, the motivation to buy the suits contributed to income production and business goodwill. While not deductible, the expense may be capitalized to the business. Possibly the taxpayer may amortize the cost of the suits over fifteen years ${ }^{29}$ or at least recover the cost, for tax purposes, upon the sale or abandonment of the practice. $^{30}$ The example would allow a non-deductible personal expenditure to become a income-production capital expenditure by attaching itself to income-production property - exactly as occurred in Gilmore. ${ }^{31}$ Of course, it seems obvious that the taxpayer's arguments would fail in both examples. Neither example finds support in administrative materials or decisional law.

\footnotetext{
${ }^{27}$ Gilmore v. U.S., supra note 1.

${ }^{28} 290$ U.S. 111 (1933), where the taxpayer was not permitted to deduct payments to creditors of the bankrupt corporation he owned. The Court observed that the payments were business, rather than personal, payments but were not deductible because they did not meet the "ordinary" side of the ordinary and necessary test under what is now I.R.C. $§ 162$. As necessary business payments, the expenditures probably were capital and became part of the goodwill of the new business although resolution of that issue was unnecessary to the case.

${ }^{29}$ I.R.C. $\$ 197$ may permit 15 year amortization the expenditure is part of self-created goodwill that is not amortizable under I.R.C. $\$ 197(c)(2)$.

${ }^{30}$ I.R.C. $\$ \S 1001,1011$.

${ }^{31}$ Gilmore v. U.S., supra note 1.
} 
The Gilmore remand ${ }^{32}$ belongs to a line of decisions that fail to achieve theoretically consistent tax outcomes at the border between current expenses and capital expenditures. This article examines some of those decisions ${ }^{33}$ and observes that the failure emanates from historically narrow delineation of boundaries between current and capital expenditures. The article argues that the fundamental tax principle underlying the decisions in Commissioner v. Idaho Power Co. ${ }^{34}$ and INDOPCO, Inc. v. Commissioner, ${ }^{35}$ and section $263 \mathrm{~A}$ of the $\operatorname{Code}^{36}$ is that the primary, and probably only, difference between current and capital expenditures is their relational duration. Relational duration refers to the life of any specific expenditure in relation to a specific taxpayer and use. A current expense is self-contained in its duration. The taxpayer consumes the expenditure, so that its duration approaches zero in relation to the specific taxpayer's use. By contrast,

\footnotetext{
${ }^{32}$ Gilmore v. U.S., supra note 1.

${ }^{33}$ For example, Pittsburgh Milk Co. v. Commissioner, 26 T.C. 707 (1956), discussed infra in text commencing with note 175, and Max Sobel Wholesale Liquors v. Commissioner, 630 F.2d 670 ( $9^{\text {th }}$ Cir. 1980), discussed infra in text commencing with note 161.

${ }^{34} 418$ U.S. 1 (1974).

35503 U.S. 79 (1992)

${ }^{36}$ Section 803(a) of the Tax Reform Act of 1986, P.L. $99-514$ (October 22, 1986), added section 263A to the Code requiring capitalization of indirect costs for property, including inventory, and expressly linking inventory and capital expenditure concepts. The statute exempts taxpayers who acquire, rather than produce, property for resale and have gross receipts of $\$ 10$ million or less from the rules. I.R.C.
} $\S 263 A(b)(2)(B) . \quad$ Section 1008(b)(1) of the Technical and Miscellaneous Revenue Act of 1988, P.L. 100657 (November 10,1988), added the last sentence to I.R.C. §263A(a). See discussion infra in Part V. 
another taxpayer using the identical expenditure to create or enhance property must measure the expenditure's duration with respect to the property affected.

For example, a builder uses materials and pays labor to build a structure. The owner pays the builder on a current basis -- rather than for a completed structure. To the builder, the materials and labor are current expenses. ${ }^{37}$ Once he expends them, they are no longer his. He has consumed them in his business by incorporating the materials and labor into a building he does not own. For the owner, however, the same materials and labor are capital expenditures because they have become absorbed into his building. In relation to the owner, the duration of the materials and labor is a function of the life of the building in the owner's hands. ${ }^{38}$

No expenditure is inherently current or capital. The use of the expenditure and the identity of the party making the expenditure define it as current or capital. ${ }^{39}$

\footnotetext{
${ }^{37}$ I.R.C. $\$ 162$.

${ }^{38}$ Historically, relational duration was a frequent matter of contention between taxpayers and the government for depreciable property until I.R.C. $\$ 168$ fixed the depreciable lives of tangible property, in most cases without regard to the nature of the taxpayers trade or business. See, for example, Hertz Corp. v. U.S., 268 F.2d 604, 609 (1959) (determining that useful life for purposes of I.R.C. $\$ 167$ depreciation is the economic life of the property as the taxpayer uses it in the taxpayer's trade or business).

${ }^{39}$ The concept of the same expenditure or property having different characteristics with respect to function to different people is commonplace. A television, for example, is inventory to the vendor (I.R.C. $\S$ 1221(a)(1)), equipment to a motel operator (I.R.C. § 1221(a)(2)), and a capital asset when used in a personal residence. Compare the manner in which one protects a security interest in the television under U.C.C. Article 9.
} 
Relational duration not only separates current from capital expenditures but also reveals that the cost of goods in inventory accounting is a variant of the immediate consumptiondurable incorporation theme. Thus, capital expenditures and inventory costs are conceptual equivalents. ${ }^{40}$

Idaho Power ${ }^{41}$ and INDOPCO ${ }^{42}$ correctly view expenditures through the lens of section 161 of the Code and illustrate that various provisions expressly allowing deductions ${ }^{43}$ remain subservient to a series of special limitations. ${ }^{44}$ Those special limitations include rules of capitalization, ${ }^{45}$ personal expenditure non-deductibility, ${ }^{46}$ and related taxpayer transactions ${ }^{47}$ that come into play only after the deduction provisions determine that the taxpayer otherwise may take the item into account. ${ }^{48}$ Hence this article will argue that all restrictions within a deduction statute apply to capitalization as

\footnotetext{
${ }^{40}$ As Congress seems to have observed when it enacted I.R.C. $§ 263$ A in 1986 . See discussion of inventory commencing with the text accompanying note 128 infra and of I.R.C. $§ 263 \mathrm{~A}$ in Part V.

${ }^{41}$ Supra note 34 at $17-18$.

${ }^{42}$ Supra note 35 at 84 .

${ }^{43}$ I.R.C. $\$ 162$ et seq.

${ }^{44}$ I.R.C. $\$ 261$ et seq.

${ }^{45}$ I.R.C. $\S \S 263,263 \mathrm{~A}$.

${ }^{46}$ I.R.C. $\$ 263$.

${ }^{47}$ I.R.C. $\$ 267$.

${ }^{48}$ For example, the taxpayer in Idaho Power, supra note 34, could take only the current depreciation allowance on the equipment under I.R.C. $§ 167$ into account in determining how much to capitalize.
} 
well. Application of that principle would have generated a different and theoretically sound outcome in Gilmore, ${ }^{49}$ Pittsburgh Milk ${ }^{50}$ and Max Sobel. ${ }^{51}$

This article will demonstrate that there are three critical questions for any expenditure: (1) is the expenditure in the taxpayer's personal or income-producing world? (2) may the taxpayer take the expenditure into account? and (3) if the answer to (2) is yes, does the expenditure incorporate into property the taxpayer owns? Part II of this article will examine further certain personal world expenditures. Then part III will move to the income-producing world and the issues of taking an expenditure into account and the current-capital border. Part IV will relate the current-capital dichotomy and the question of taking an expenditure into account to inventory accounting. Part V will argue that Idaho Power, INDOPCO, and section 263A make identical rules for taking expenditures into account applicable to current, capital, and inventory expenditures and eliminate any historical confusion that case law may have produced.

\section{Personal World: Capital Expenditures.}

Within a taxpayer's personal world, there is little tax controversy concerning expenditures. With some exceptions, ${ }^{52}$ no significant, immediate tax dollars are at stake.

\footnotetext{
${ }^{49}$ Supra note 1.

${ }^{50}$ Supra note 33.

${ }^{51}$ Supra note 33.
} 
To a limited extent, taxpayers prefer personal expenditures to be capital, rather than current, because upon disposition of the property that the capital expenditure enhances gains are subject to tax. ${ }^{53}$ But much personal use property that appreciates materially over time never becomes subject to the income tax upon disposition. Either the taxpayer continues to hold the personal use property until her death, so that the basis adjustment to date of death value eliminates the gain, ${ }^{54}$ or the personal use property is a personal residence subject to the exclusion of all or part of its gain. ${ }^{55}$

Intriguing, but likely unanswerable, questions abound in the personal world because they never (or nearly never) take on tax significance. For example, consider a taxpayer who pays $\$ 500$ to replace the tires on his personal use automobile. Presumably the purchase is a capital expenditure that increases the taxpayer's adjusted basis in the car. It cannot be a current, non-deductible expenditure because the tires have a long useful life. Now assume those tires wear out and the taxpayer replaces them a second time for $\$ 500$. Is the taxpayer's adjusted basis in the car the original purchase price plus $\$ 500, \$ 1000$ or zero? In order to avoid introducing a depreciation concept into personal

\footnotetext{
${ }^{52}$ Taxpayers and the government may disagree, for example, on matters such as whether personal interest expenditures are deductible qualified residence interest under I.R.C. §163(h)(3) rather than non-deductible personal interest.

${ }^{53}$ I.R.C. $\S 61(a)(3)$ and I.R.C. $\$ 1001$ include no exception for personal use property.

${ }^{54}$ I.R.C. $§ 1014$.

${ }^{55}$ I.R.C. $\S 121$ excludes as much as $\$ 250,000$ ( $\$ 500,000$ for taxpayers filing joint returns) of gain on the sale of the taxpayer's principal residence.
} 
use property, ${ }^{56}$ the answer should be plus $\$ 1000$. Depreciation on personal use property conflicts with the strict valuation concept necessary for the measurement of deductible casualty losses. $^{57}$

Purchase of a third set of tires is an abandonment or retirement of the second set, so that the basis attributable to the second set should disappear, similar to the cost of the architect's plans in the earlier example. ${ }^{58}$ While theoretically sensible, that result leaves a void with respect to the original equipment tires unless one allocates the purchase price of the car among its component parts and reduces the basis each time the taxpayer replaces a part. Such tracking of basis change is cumbersome and impractical - but then tracking the adjusted basis of a personal use automobile is unnecessary, since a car's value at any moment in the car's useful life is almost invariably less than its basis. If the taxpayer converts the car to business use, its lower than basis value would become its depreciable basis. ${ }^{59}$ A peculiar market condition, which causes the car to appreciate in value, would result in the taxpayer having too large a basis and, upon conversion to business use, to recover through depreciation both the basis attributable to the retired original and first

\footnotetext{
${ }^{56}$ I.R.C. $\$ 167$ (a) applies only to property used in the trade or business or held for the production of income.

${ }^{57}$ I.R.C. $§ 165$ (a) limits the deductible loss in all cases to the "loss sustained during the taxable year." If the property lost value in the ordinary course of events, as automobiles tend to do, and then a casualty occurs, the statute limits the casualty loss to the value at the moment before the casualty occurred. Treas. reg. $\S$ $1.165-7(b)$.

${ }^{58}$ See text accompanying note 24 supra.

${ }^{59}$ Treas. reg. $§ 1.167(\mathrm{~g})-1$.
} 
replacement set of tires. ${ }^{60}$ Probably that circumstance would be sufficiently unusual that the government would not be likely to dispute the taxpayer's computation of adjusted basis.

Nevertheless, a taxpayer generally takes the adjusted basis of property she discards into account at the moment of abandonment. ${ }^{61}$ The taxpayer's adjusted basis in her clothing, books, and household appliances does not shift to replacement items. Rather it disappears when the taxpayer discards the items. If the taxpayer does not discard the items, and they subsequently become valuable, as antiques, for example, gain on sale is the excess of sale price over the taxpayer's historical basis in the item. ${ }^{62}$ The adjusted basis in the old item does not transfer to replacement property and does not leave the replaced property with a zero basis.

In dealing with personal residences, the underlying question of basis attributable to multiple replacements takes on somewhat greater significance. A taxpayer may replace the kitchen several times during her period of ownership. A new kitchen is a capital expenditure in the personal world that increases the adjusted basis, and presumably also the value, of the house. But what about the old kitchen, does the taxpayer reduce her basis by the portion of the original purchase price properly allocable

\footnotetext{
${ }^{60} I d$. This would be an instance where the taxpayer's adjusted basis rather than value on the date of conversion would control depreciation.

${ }^{61}$ Thor Power Tool Co. v. Commissioner, 439 U.S. 522 (1979) (requiring that the taxpayer abandon its spare parts before it may deduct the loss on the inventory).

${ }^{62}$ I.R.C. $§ 1001$.
} 
to the kitchen that no longer is part of the house? As the previous paragraphs indicate, sound tax theory requires that the withdrawal and disposal of the old kitchen reduce the basis of the house. ${ }^{63}$ The practical answer, however, is that the taxpayer does not reduce her adjusted basis for the old kitchen, nor for the deterioration of the roof or any other element of the house. ${ }^{64}$ If the taxpayer replaces the kitchen several times, the taxpayer has abandoned the immediately preceding replacement kitchen and the basis attributable to that kitchen should disappear. Apparently it does not, lest the adjusted basis attributable to the original kitchen also disappear, thereby requiring that the taxpayer ascertain the purchase price of each component of a house when she first acquires it. ${ }^{65}$

\footnotetext{
${ }^{63}$ Since 1984, I.R.C. $\$ 280$ B requires taxpayers to capitalize demolition costs and basis of demolished structures to the land and may apply to the kitchen through Treas. reg. $\S 1.280 \mathrm{~B}-1(\mathrm{~b})$ and Treas. reg. $\S$
} 1.48-1(e)(2). While capitalizing the demolished kitchen to the land or the building will have the same effect to the taxpayer upon sale of the house, capitalizing to the building will produce a tax benefit in the case of destruction of the building in a casualty under I.R.C. §165(c)(3) or through depreciation allowances under I.R.C. $\$ 168$ if the taxpayer converts the house to an income-producing use. For business property, historically, Treas. reg. § 1.165-3(b) allowed a deduction for the cost of demolition and the adjusted basis of the building demolished so long as the intent to demolish formed after acquisition of the building. Hence if the same rule applied to personal use property, demolition of the old kitchen would generate a current event that the taxpayer could not take into account under I.R.C. §262. If, however, the taxpayer formed the intent to demolish before or contemporaneously with the acquisition, i.e., the taxpayer acquired intending to demolish and replace, the adjusted basis of the demolished building and the cost of demolition forms part of the basis of the new building. Treas. reg. § 1.165-3(a).

${ }^{64}$ I.R.C. $\$ 1016(a)(2)$ requires an adjustment to basis only to the extent of deductions allowed or allowed for depreciation, but I.R.C. $\S 167$ allows no deduction for the depreciation of personal use property.

${ }^{65}$ A simple, but unacceptable, solution to both the tire and the kitchen problem might be to view those items as replacements for which the taxpayer receives no increase in basis as is the case with a repair of a 
Since adjusted basis is significant for personal use property only when the taxpayer disposes of it at a gain or converts it to business use, analogies to other dual basis rules may clarify the excess basis problem. For example, the gift basis rule applicable to gifts of property that has depreciated in value preserves basis for purposes of computing gain only. ${ }^{66}$ Under that analogy, the recovery of both kitchen investments on sale of the property seems to be the correct result. So long as the tax law treats the property as a whole and not a separate component, the old kitchen remains part of the property because the taxpayer has received no tax benefit for the loss of investment in the old kitchen. Accordingly, the taxpayer may recover her full investment upon the sale of the house at a gain. ${ }^{67}$ Similarly, a disallowed loss on a sale to a related party becomes allowable to the related purchaser when she sells the property at a gain. ${ }^{68}$

broken window, for example. Since the taxpayer has invested additional funds into the property, no increase in basis fails to comport with the reality of the investment.

${ }^{66}$ Under I.R.C. $\$ 1015$, the donee's basis in property that is less valuable than its basis on the date of the gift is the fair market value on the date of the gift so long as the donee sells the property at a loss. If the donee sells the property at a gain, however, the basis is the donor's basis at the time of the gift. For an extended discussion of the donee's dual basis in loss property, see Robert I. Keller, At a Loss: A Half Century of Confusion in the Tax Treatment of Transfers of Depreciated Property between Related Taxpayers, 44 TAX LAW. 445 (1991).

${ }^{67}$ An analogy to suspended losses might support the conclusion as well under a transactional accounting model similar to the passive activity loss limitations. I.R.C. $\S 469$. There the taxpayer matches loss from passive activities with income from passive activities and deducts excess losses when she realizes them economically upon termination of the investment.

${ }^{68}$ I.R.C. $§ 267(d)$. 
While the analogies suggest that taxpayers may take some disallowed losses into account in the computation of gain, they are not wholly apt analogies in the personal world. The analogies all concern losses that meet the general criteria for deductibility because they involve property the taxpayer holds in her income-producing world. ${ }^{69}$ The limitation on deductibility of the loss reflects a special policy concern, such as manipulation of loss timing without a true disposition in a sale to related party, ${ }^{70}$ rather than non-deductibility of losses other than casualty losses in the personal world. ${ }^{71}$

Conversion of the personal use property to business use highlights the basis problem. ${ }^{72}$ If a taxpayer receives as a gift personal use property that has declined in value and converts the property to income-producing property, the gift basis rule limits her basis for depreciation purposes to the fair market value on the date of the gift. $^{73}$ Increase in the property's value following the gift, but before conversion, does not alter this result. Once the donor makes the gift, the pre-gift decline in value becomes a permanent feature of the property's basis. For other personal use property, fair market value is only significant at the moment of conversion. Where no gift is involved, pre-

\footnotetext{
${ }^{69}$ I.R.C. $\S 165(c)(1),(2)$.

${ }^{70}$ I.R.C. $§ 267(a)(1)$. See generally, Keller, supra note 66.

${ }^{71}$ I.R.C. $\S \S 165(\mathrm{c})(3), 262$.

${ }^{72}$ See, generally, on conversion of a personal residence, Vernon M. Martin, Jr. and Sandra K. Miller, Temporarily Converting a Personal Residence to Income Producing Property: Careful Planning in Advance of a Conversion Can Maximize Tax Savings, 2-94 Tax Advisor 107 (1994).

${ }^{73}$ I.R.C. $\S 1015(\mathrm{a})$.
} 
conversion fluctuations in value do not become a permanent feature of the property's basis. Only the fair market value on the date of conversion limits the depreciable basis. A loss in value before conversion before conversion becomes inconsequential if an increase in value before conversion follows. ${ }^{74}$ So long as the value of the property at the time of conversion is equal to or greater than the taxpayer's adjusted basis, the adjusted basis becomes the depreciable basis despite its inclusion of items like the abandoned kitchens. ${ }^{75}$ Even if the possible application of the demolition rule limits the taxpayer's depreciation allowances, ${ }^{76}$ following conversion to income-producing property, the taxpayer certainly may deduct the cost of the several replacement kitchens as a loss upon sale of the property. ${ }^{77}$

\section{Income-Producing World: The Concepts of "Taking into Account" and "Relational Duration".}

While the difference between current expenses and capital expenditures generally is not critical in the personal world, the preceding part demonstrates that there are occasions on which the tax distinction becomes significant to the taxpayer even in the personal world. Since tax rules do distinguish current from capital, the distinctions ought to be comparable in the taxpayer's personal and income-producing worlds. Replacement of a broken window, for example, is a current expense in both worlds - non-deductible as

\footnotetext{
${ }^{74}$ Treas. reg. $\S 1.167(\mathrm{~g})-1$.

${ }^{75} I d$.

${ }^{76}$ I.R.C. $\$ 280 B$.

${ }^{77}$ I.R.C. $\$ 165(c)(2)$.
} 
a personal living expense in the person world, ${ }^{78}$ deductible as an ordinary and necessary business expense in the taxpayer's trade or business. ${ }^{79}$ Replacement of the broken window with a materially different, more expensive, more durable window, even though replacement became necessary because of breakage, probably is a capital expenditure in both worlds because it increases the value of the property. ${ }^{80}$

In the personal world, the taxpayer willingly accepts capitalization. ${ }^{81}$ In the income-producing world, the repair/capital expenditure distinction has been the source of considerable controversy and litigation. The business taxpayer prefers to classify the expenditure as a repair in order to claim the immediate deduction. In Mt. Morris DriveIn Theatre Co. v. Commissioner, ${ }^{82}$ for example, the taxpayer unsuccessfully argued that the drainage system it installed in response to a neighbor's lawsuit was a repair. The drainage system was a permanent improvement to the property that was essential from the outset. According to the court, the drainage system completed the construction of the drive-in theater. But in Plainfield-Union Water Co. v. Commissioner, ${ }^{83}$ the taxpayer

\footnotetext{
${ }^{78}$ I.R.C. $§ 262$.

${ }^{79}$ I.R.C. $§ 162$.

${ }^{80}$ Treas. reg. $\S 1.263(\mathrm{a})-1(\mathrm{a})(1)$.

${ }^{81}$ Occasionally, ordinary treatment for a specific deductible expense in the personal world does benefit the taxpayer. In Cherry v. Commissioner, 46 T.C.M. (CCH) 1031 (1983), the taxpayer argued successfully that installation of a swimming pool was medically necessary and a deductible medical expense under I.R.C. $\S 213$.

${ }^{82} 25$ T.C. 272 (1955), aff'd. 238 F.2d 85 (1956).

8339 T.C. 333 (1962) (non-acq.).
} 
water company successfully argued that lining its pipes with cement to prevent clogging was a deductible repair and not a capital expenditure because the expenditure preserved the life of the pipes but did not extend it.

In the taxpayer's income-producing world, all expenditures fit within one of four categories. If the taxpayer may take the expenditure into account, ${ }^{84}$, the expenditure is either (1) current and deductible or (2) capital and includable in basis because the expenditure absorbs into and becomes part of property that the taxpayer does not consume immediately in her income-producing activity. If the taxpayer may not take the expenditure into account, ${ }^{85}$ the expenditure is (3) current but not deductible usually on account of a countervailing tax policy or (4) capital but not includable in basis despite the expenditure becoming part of property the taxpayer does not consume immediately.

In Mt. Morris ${ }^{86}$ and Plainfield-Union Water Co. ${ }^{87}$ the taxpayer could take the expenditures into account and, in both instances, were absorbed into the property so that the expenditures seemed to belong to category (2) above. But, like the repair of the broken window, in Plainfield-Union Water Co., the expenditures did not enhance the property but only restored it to the quality and character that it had lost. Although they become permanently part of the property they affect, repairs are current and deductible

\footnotetext{
${ }^{84}$ So that the answer to critical question (2) in the introduction is yes, supra, text following note 51.

${ }^{85}$ So that the answer to critical question (2) in the introduction is yes, supra, text following note 51.

${ }^{86}$ Supra note 82.

${ }^{87}$ Supra note 83 .
} 
category (1) expenditures because they do not alter the use or enhance the value of the property relative to its state before the damage occurred. A more principled approach to repairs might be to allow the taxpayer a current loss deduction for the broken or damaged item and to require capitalization of the repair. Since the repair neither enhances the value nor extends the useful life of the underlying property, its depreciable life would be the remaining depreciable life of the property into which it absorbs. Allowance of a current deduction for the repair is a tax shortcut rather than application of sound, consistent tax theory.

In the income-producing world, there are many current expenditures that taxpayers may not take into account, ${ }^{88}$ and, therefore, may not deduct. Compensation that is not reasonable in amount, ${ }^{89}$ illegal payments to government officials, ${ }^{90}$ fines and penalties, ${ }^{91}$ and interest on indebtedness the taxpayer uses to carry tax-exempt bonds, ${ }^{92}$ are examples of non-deductible current expenditures. Moreover, there are amortization allowances for term interests that a taxpayer receives by gift and may not deduct, ${ }^{93}$ but

\footnotetext{
${ }^{88}$ That is they generate negative responses to critical question (2), Supra, text following note 51.

${ }^{89}$ I.R.C. §162(a)(1).

${ }^{90}$ I.R.C. §162(c)(1).

${ }^{91}$ I.R.C. §162(f).

${ }^{92}$ I.R.C. $\$ 265(a)(2)$.

${ }^{93}$ I.R.C. $\$ 273$.
} 
that are nevertheless subject to reduction in basis with the passage of time. ${ }^{94}$ Some expenditures are not deductible because the taxpayer has misidentified personal world expenditures as income-producing. For others non-deductibility does not imply that expenditures are personal or in some other way unrelated to the conduct of the taxpayer's income producing activities. Rather Congress has determined that such payments should not be deductible for policy reasons ${ }^{95}$ or in order to protect or increase tax revenues. ${ }^{96}$

An example of tax world misclassification might be a sole proprietor whose business requires her to employ a maintenance person to handle general business property maintenance. The maintenance person's salary is a deductible ordinary and necessary

\footnotetext{
${ }^{94}$ Treas. reg. $\S \S 1.1014-4,-5$ describe the operation of the uniformity of basis rule. The amortization allowance for the term interest holder corresponds, albeit imperfectly, to the basis increase in the remainder.

${ }^{95}$ Deductibility of fines that are not deductible because of I.R.C. §162(f), for example, might undercut the impact of a governmental entity's mechanism for enforcement of its laws or regulations. See Tank Truck Rentals, Inc. v. Commissioner, supra note 16, preceding enactment of I.R.C. §162(f), a trucking company that ran trucks overweight in violation of state law could not deduct the overweight fines for fear of undercutting state enforcement of its laws.

${ }^{96}$ I.R.C. $\$ 265$ denies deductions for expenses and interest, otherwise properly deductible as ordinary and necessary, incurred to produce tax-exempt income. I.R.C. $§ 67$ limits the deductibility of items deductible under I.R.C. $\$ 212$ in order to raise revenue. See Jnt. Comm. on Taxation, General EXPLANATION OF THE TAX REFORM OF 1986 at 76-81 (1987) explains the provision as reducing complexity and adjusting for some expenditures that are personal in nature but discloses a sizable revenue increase from the provision averaging $\$ 5$ billion per year over the first five years.
} 
business expense for the sole proprietorship. ${ }^{97}$ The maintenance person builds a gazebo at the taxpayer's personal residence. That portion of the maintenance person's salary that is attributable to building the gazebo is no longer deductible but is a personal expenditure of the sole proprietor taxpayer. The allocable portion of the salary becomes part of the cost of the gazebo. ${ }^{98}$ Even if the taxpayer asserted that she sometimes needed the gazebo to entertain business guests there, the expenditure still becomes part of the basis in the gazebo. The taxpayer may neither deduct the expenditure nor add it to her basis in her business property. ${ }^{99}$ If, however, she uses the gazebo exclusively to entertain business guests, and the entertaining of business guests is ordinary and necessary to the business, ${ }^{100}$ the gazebo becomes depreciable business property, including the maintenance person's salary allocable to the gazebo. This characterization of the salary expenditure is historically correct. ${ }^{101}$

An example of a deductible, current expenditure is a monthly rental payment for the use of office space. ${ }^{102}$ To observe the relational duration relationship between a currently deductible rent expense and a capital expenditure, one need only assume that the taxpayer pays rent for the use of an office for several years in a single payment. The

\footnotetext{
${ }^{97}$ I.R.C. $\$ 162$.

${ }^{98}$ I.R.C. $\$ 263$.

${ }^{99}$ And see I.R.C. $\S 280 \mathrm{~A}$ for limitations on deductibility for business use of one's residence.

${ }^{100}$ I.R.C. $\$ 274$ limits deductions for entertainment facilities and activities.

${ }^{101}$ Enactment of I.R.C. $§ 263 \mathrm{~A}$ in 1986 neither created nor altered this analysis.

${ }^{102}$ I.R.C. $\$ 162(a)(3)$ or I.R.C. $\$ 212(2)$.
} 
rental payment is no longer a current, consumed expenditure but becomes a property in its own right. It is a leasehold interest that the taxpayer must amortize over its term. ${ }^{103}$ There is some payment-use duration that precludes treating the expenditure as currently deductible. In theory, that durational limit ought to be the current tax year. As the United States assesses income taxes for one-year tax periods, ${ }^{104}$ any payment that provides a use benefit to the taxpayer beyond the close of the taxable year should be allocated between taxable years in order to match income and expenditure accurately. ${ }^{105}$ However, as a matter of convenience, taxpayers generally may deduct expenditures that

${ }^{103}$ I.R.C. $\$ 167$ refers to depreciation but customarily amortization is the term applicable to intangible property such as leasehold. Richard A. Westin, WG\&L TAX DictionaRY 36 (2000).

${ }^{104}$ I.R.C. $\S 441$.

${ }^{105}$ I.R.C. $\S 446(b)$. The government may require a cash basis taxpayer to allocate expenses over multiple years in order to reflect income accurately. And, see, INDOPCO, supra note 35 and text accompanying and following note 221 infra, that seems to settle that benefits extending beyond the current taxable year are capital expenditures. Practitioners expressed considerable concern about the repercussions of the decision. See Lee A. Sheppard, INDOPCO Repeal Rolls Forward, 96 TAX Notes 1438 (2002). The Department of the Treasury promulgated taxpayer favorable regulations under I.R.C. $\$ 263$ at the end of 2002, proposed treas. reg. § 1.263(a)-4, inter alia, 67 FR 77701 (December 19, 2002) that allayed many concerns but have been criticized for excessive generosity to taxpayers. Calvin H. Johnson, Destroying Tax Base: The Proposed INDOPCO Capitalization Regulations, 99 TAX NOTES 1381 (2003). At the end of 2003, Treasury promulgated final regulations, Treas. reg. §1.263(a)-4 and 1.263(a), inter alia, T.D. 9107 (December 22, 2003). For criticism, see Lee A Sheppard, More Giveaways In Final Intangibles Capitalization Rules. 102 TAX NOTES 12 (2003). 
provide a use benefit of one year or less even when the benefit straddles two taxable years. $^{106}$

That the current/capital distinction is a function of duration is fundamental to taxation. Consider that the taxpayer devotes the rented office to activities involved with constructing a building for use in her business. The taxpayer's basis in the new building includes the rent the taxpayer pays for use of the office space. ${ }^{107}$ Since 1986 , the Code expressly requires the taxpayer to treat most indirect costs in the same manner as direct costs of producing or improving property. ${ }^{108}$ However, the taxpayer may capitalize only items of expenditure that, but for the rule of capitalization, "could ... be taken into account in computing taxable income." ${ }^{\prime 109}$ Thus, only the current portion of the advance

\footnotetext{
${ }^{106}$ Rev. Rul. 69-560, 1969-2 C.B. 25 (useful life of tires and tubes less than one year so currently deductible even if the use straddles taxable years). Similarly, small expense items or property are deductible even if they long useful lives under Treas. reg. $§ 1.162-12(a)$. There are many exceptions to this principle where opportunities exist to derive a significant tax benefit, for example, I.R.C. §706(d) limits deductibility in the case of a partnership. I.R.C. $\S 467$ prevents taxpayers from overstating current rent in order to capture a tax benefit.

${ }^{107}$ Commissioner v. Idaho Power, supra note 34, (taxpayer required to allocate and capitalize equipment depreciation in constructing a power plant for use in its business in addition to capitalizing amounts actually paid out). Rent is an amount paid out.

${ }^{108}$ I.R.C. $\$ 263 \mathrm{~A}(\mathrm{a})(1)(B)$. The Tax Reform Act of 1986 added section $263 \mathrm{~A}$ to the Code requiring capitalization of indirect costs for property, including inventory. See discussion infra in Part V.

${ }^{109}$ I.R.C. $\$ 263 \mathrm{~A}(\mathrm{a})(2)$, last sentence. Congress added the specific language limiting capitalization to costs that the taxpayer otherwise could take into account with section 1008(b)(1) of the Technical and Miscellaneous Revenue Act of 1988, P.L. 100-647. The House Report to the bill provides the example of
} 
payment of rent becomes a capital expenditure, even though the taxpayer is on a cash basis of accounting and pays several years' rent during the current year. It is doubtful that pre-1986 law would have permitted or compelled capitalization of the full advance payment of rent despite absence of the express limitation to amounts that the taxpayer could take into account.

Consider further a sole proprietor who pays compensation to an employee that exceeds significantly normal compensation for such an employee. Unreasonable compensation is not deductible. ${ }^{110}$ If the employee engaged in the conduct of ordinary and necessary activities for her sole proprietor employer, the employer could not deduct the excessive portion of the compensation. On the other hand, the salary of an employee who spends full time supervising the construction of new business premises for the sole proprietor becomes part of the cost of those premises. ${ }^{111}$ Case law suggests, however, that the reasonable compensation limitations may play no role with respect to capitalized expenditures. ${ }^{112}$ Hence the sole proprietor may be able to add the full salary, including

preventing the capitalization of the allocable, personal portion of a taxpayer's interest expense. Treas. reg. $\S 263 \mathrm{~A}-1(\mathrm{c})(2)$ provides as an example the non-deductible portion of business meals.

${ }^{110}$ I.R.C. $\S 162(a)(2)$.

${ }^{111}$ I.R.C. $\$ 263$.

${ }^{112}$ Max Sobel Wholesale Liquors v. Commissioner, supra note 33. Language in Max Sobel, although an inventory case, discussed infra in part IV, may constrict limitations on deductibility to ordinary and necessary expense contexts. 
the unreasonable portion of that salary to the taxpayer's adjusted basis in the premises and recover it through depreciation for tax purposes. ${ }^{113}$

Even if the business expense limit on compensation were no barrier to capitalization, ${ }^{114}$ the taxpayer cannot capitalize all unreasonable compensation, even if apparently attributable to construction. Unreasonable compensation often suggests that some other reason exists for the excess portion of the payment. Sometimes one taxpayer is making a gift to another. Historically, in the case of a transaction between a corporation and an employee who is a shareholder, the excess compensation was a disguised dividend. ${ }^{115}$ Sometimes the excess compensation might evidence extortion. For example, the payment might be for a personal service that the taxpayer seeks to characterize as a business service as in the example above. Where recharacterization is appropriate, the unreasonable portion of the compensation is not a capitalized expenditure and cannot become part of the basis in that property. It is not an "amount paid out for new buildings ..."116 but is paid out for some other and non-deductible reason.

\footnotetext{
${ }^{113}$ I.R.C. $\S 168$.

${ }^{114}$ I.R.C. $\$ 162(\mathrm{a})(2)$.

${ }^{115}$ Disguising a dividend as compensation would permit a deduction at corporate level with substantially the same inclusion and rate of tax at shareholder level. The corporation might pay the compensation to a relative of the shareholder, thereby accomplishing an assignment of income from the correct recipient to someone else, probably a lower bracket taxpayer, without liability for a gift tax. The recent reduction of the rate of tax on corporate dividends to the net capital gain rate altered the incentive for such recharacterization of dividends as compensation. See, Michelle Jewett, Characterization of Income: Compensation vs. Dividends, 103 Tax Notes 1501 (June 21, 2004).

${ }^{116}$ I.R.C. $\S 263(\mathrm{a})(1)$.
} 
Accordingly, only unreasonable compensation that is excessive for no other reason than that it is excessive may become a capital expenditure even if it would not be deductible. Such portion of unreasonable compensation forms rather a narrow band of capitalized unreasonable compensation payments.

Similar analysis may apply to bribes as well. While bribes are not deductible, ${ }^{117}$ if one bribes the building inspector to overlook a construction shortcut, case law may support including the bribe in the building's adjusted basis. ${ }^{118}$ The public policy limitation on deduction of the bribe arguably does not apply to capital expenditures because Congress failed to extend the statute to capital expenditures. ${ }^{119}$ This outcome seems unjustified and reflects a misinterpretation of the relationship between current that is, ordinary and necessary business expenses - and capital expenditures. ${ }^{120}$ The public policy against corruption of public officials is robust and ought to preclude the taxpayer from taking a bribe into account at any time - not just when its relational duration is close to zero rather than being absorbed into more durable property the taxpayer owns.

\footnotetext{
${ }^{117}$ I.R.C. $\S 162(c)(2)$.

${ }^{118}$ Max Sobel Wholesale Liquor, supra note 33, discussed infra in part IV.

${ }^{119}$ Dixie Dairies Corporation v. Commissioner, 74 T.C. 476, 492 (1980) (holding that a taxpayer's illegal price rebates to customers reduce gross revenue as in Pittsburgh Milk, supra note 33).

${ }^{120}$ I.R.C. $\$ 263 \mathrm{~A}(\mathrm{a})(2)$, last sentence may have corrected Congress’ oversight and may preclude capitalization now. See discussion infra in part V.
} 
Viewed statutorily, if the payment, whether excessive compensation or bribe, does not penetrate section 162's taking into account barrier, it cannot reach section 161 that directs it to the capitalization rules under sections 263 and 263A. The courts, however, have allowed tax benefits through inventory accounting for items that as expenses are not deductible. ${ }^{121}$ That the courts would have allowed the tax benefit under the inventory rules for a bribe despite the compelling public policy against bribery is doubtful. $^{122}$

\section{The Inventory Cases: Inventory and Capital Accounting.}

Historically, inventory may been a special case of capitalization that remained separate from other capitalization rules. ${ }^{123}$ While section 161 of the Code subordinates the deductions under sections 162 through 198 to various rules of non-deductibility, it did not subordinate inventory cost absorption until 1986 when Congress added section 263A to the Code. ${ }^{124}$ Until 1986, inventory remained solely part of the accounting rules of the

\footnotetext{
${ }^{121}$ See discussion infra part IV.

${ }^{122}$ See the pressing objectives discussion of emergency price controls in Max Sobel, supra note 33, at 673, discussed infra in text accompany note 173 .

${ }^{123}$ I.R.C. $\$ 263 \mathrm{~A}$, however, now treats inventory and other property substantially identically.

${ }^{124}$ I.R.C. $\$ 161$ refers to part IX. Part IX currently includes I.R.C. $\S \S 261$ through $280 H$, but Congress added I.R.C. §263A with the Tax Reform Act of 1986, P.L. $99-514$ (October 22, 1986).
} 
Code ${ }^{125}$ rather than the no deduction rules. ${ }^{126}$ Nevertheless, operationally determining the cost of goods sold for inventory accounting always has matched capitalization generally. ${ }^{127}$

Consider a temporary worker service that provides a machine operator to a factory. The temporary worker service consumes that machine operator's labor immediately, so, for the temporary service, the relational duration of the payment to the machine operator is approximately zero. The temporary service may deduct the cost of the payment to the machine operator currently as an ordinary business expense. ${ }^{128}$ For the manufacturer, the payment to the temporary worker service for the machine operator's labor becomes part of the manufactured goods. As the expenditure absorbs into inventory, ${ }^{129}$ its relational duration for the manufacturer is not immediate but rather a function of the manufacturer's disposition of his inventory. When a buyer purchases the manufactured product, the manufacturer consumes it in his business and takes its cost into account for tax purposes through his cost of goods sold. ${ }^{130}$ And, if a buyer uses the

\footnotetext{
${ }^{125}$ Inventories were part II of subchapter E, the accounting subchapter. Except for the cross-references, such as the reference I.R.C. $\S 161$, placement of a provision in a location in the Code has no operational significance.

${ }^{126}$ Part IX of subchapter B, the tax computation subchapter.

${ }^{127}$ At least as Idaho Power, supra note 34, and INDOPCO, supra note 35, express the rules of capitalization. See discussion infra in part V.

${ }^{128}$ I.R.C. $\S 162$.

${ }^{129}$ I.R.C. $\S 471$.

${ }^{130}$ Treas. reg. $\S 1.471-11$. Inventory accounting includes in the taxpayer's gross income the excess of gross revenues less returns over the cost of goods sold. Treas. reg. § 1.61-3(a). Cost of goods sold is opening
} 
manufactured product as equipment, the buyer's relational duration of the product is its useful life as equipment. The buyer takes its cost into account for tax purposes through depreciation, ${ }^{131}$ and may have to capitalize the depreciation into other property produced using the manufactured product. ${ }^{132}$

Ancillary tax consequences tend to be independent of the current-capital categorization. For example, if the manufacturer in the previous paragraph pays the temporary worker service with manufactured goods instead of cash, the manufacturer's disposition of the goods is a taxable event yielding gross revenue equal to the fair market value of the goods. ${ }^{133}$ The payment is a substitute for, and durationally the same as, a

inventory plus additions less closing inventory. Any increase in the cost of goods sold, whether due to a reduction in closing inventory (as in Max Sobel, supra note 33 and discussion infra in text commencing with note 163) or an increase in additions because of absorption of costs into inventory, decreases gross income. See, generally, Lawrence A. Cunningham, InTRODUCTORY ACCOUnTING, FINANCE AND AUditing FOR LAWYERS 67-83 (St.Paul 2004).

${ }^{131}$ I.R.C. $\S 168$.

${ }^{132}$ I.R.C. $\S 263 \mathrm{~A}$.

${ }^{133}$ Treas. reg. $§ 1.83-6(\mathrm{~b})$ deals with appreciated property and correctly treats a payment with appreciated property as a sale of the property to the service provider for the amount the service provider must include in income. Possibly the regulation requires the manufacturer simply to recognize gain equal to the excess of the temporary service's inclusion over the manufacturer's basis under I.R.C. $\S 1013$. A better and more consistent tax analysis demands that general inventory accounting rules apply. Since inventory accounting does not utilize one sale, one adjusted basis under I.R.C. $\S 1001$, but instead matches revenue from all sales for the year with the cost of goods sold, the manufacturer should include the amount the temporary service included in its income as an item of gross revenue. 
cash payment. The manufacturer should treat the payment with goods in the same manner as it would a cash payment and include the value of the manufactured goods in its inventory cost. ${ }^{134}$ The temporary worker service includes the fair market value of the manufactured goods in its income. ${ }^{135}$ The temporary service takes a basis in the goods equal to the amount it included in its income. ${ }^{136}$ When the temporary worker service pays the machine operator in kind with all or part of the manufactured goods it received, the goods are considered sold for their fair market value. ${ }^{137}$ While that value may be identical to the amount the temporary service included in income upon receipt, the temporary service will recognize gain or loss on that sale whenever the value is not identical. ${ }^{138}$ Since the temporary service has paid its worker, it may deduct the payment

${ }^{134}$ Id. Treas. reg. $§ 1.83-6(a)(4)$. This may appear circular but viewing the circle as cash reveals the correctness of the approach. Imagine that the manufacturer sells the goods and the temporary service pays cash. The manufacturer then pays the temporary service with cash. That latter payment is for services that create inventory and the manufacturer must include the payment in inventory cost.

${ }^{135}$ I.R.C. $\S 83(a)$. Fair market value is a somewhat subjective concept and the temporary worker service and the government may disagree on the value to the temporary worker service of the manufactured goods and, thus, the amount of inclusion in its income. The provision is a statutory manifestation of the exchange equivalency doctrine. The doctrine assumes that if parties are dealing at arms' length, the value of the consideration one party receives is equal generally to the value of the consideration the other party receives. If the exchange is unequal, it is likely that non-disclosed consideration, a contribution to capital, or possibly a gift, is involved. See, Philadelphia Park Amusement Co. v. U.S., 126 F. Supp. 184 (Ct.Cl. 1954), the taxpayer exchanged a bridge for the extension of a franchise that was difficult to value.

136 Treas. reg. $\S 1.61-2(d)(2)(i)$.

${ }^{137}$ Treas. reg. $\S 1.83-6(b)$.

${ }^{138}$ I.R.C. $§ 1001(a)$, (c) and Treas. reg. $§ 1.83-6(b)$. 
as an ordinary and necessary business expense. ${ }^{139}$ By the same token, the machine operator includes the value of the payment in her income. ${ }^{140}$ The machine operator's basis in the property is the amount she included in income upon its receipt. ${ }^{141}$

Since only relational duration, and not some intrinsic characteristic of the expenditure, distinguishes current from capital, ${ }^{142}$ determination of whether or not a payment should be taken into account should precede determination of its relational duration. ${ }^{143}$ Case law suggests, however, relational duration for inventory takes precedence over limitations on taking an expenditure into account. ${ }^{144}$ Assume that in the preceding example, state law prohibits any payment to an unlicensed machine operator. The machine operator has no license. Further, the law is valid and the state generally enforces it. ${ }^{145}$ Since the illegality of the payment seems to have nothing to do with

${ }^{139}$ I.R.C. $\S \S 162(a)(1), 83(h)$.

${ }^{140}$ I.R.C. $\S 83(a)$.

${ }^{141}$ Treas. reg. $§ 1.61-2(d)(2)(i)$.

${ }^{142}$ See text accompanying notes 32 through 36 supra.

${ }^{143}$ As discussed earlier, I.R.C. $§ 161$ seems to have that operational function generally, supra discussion in text commencing with note 124 .

${ }^{144}$ Pittsburgh Milk, supra note 33, discussed infra in text commencing with note 174, and Max Sobel, supra note 33, discussed infra in text commencing with note 161.

${ }^{145}$ I.R.C. $\$ 162(c)(2)$ stipulates that the taxpayer loses the deduction for an illegal payment expense only if the law that makes the payment illegal is generally enforced. Note, however, that deductibility may depend upon whether the payment is just an ordinary salary payment that the state has chosen to make illegal in which case I.R.C. §162(c)(2) might not apply, compare Commissioner v. Sullivan, supra note 16, with a 
relational duration of the payment, ancillary tax consequences with the altered fact should remain independent of that current-capital determination.

While the machine operator's and the temporary service's inclusions in income do not change, as illegal income is taxable, ${ }^{146}$ comparison of the results of the changed fact with the previous results ${ }^{147}$ discloses one certain change and two possible, additional changes. The certain change is that the temporary service loses its deduction for the payment in kind to the machine operator. ${ }^{148}$ This ancillary consequence is tied to a statute applicable expressly to current expenditures ${ }^{149}$ and indirectly to capitalization. ${ }^{150}$ Under the analysis in this article, the concept of ordinary and necessary functionally determines whether or not the taxpayer takes something into account and not whether the expenditure is current or capital. ${ }^{151}$ Since an inclusion in inventory cost is only

state that makes the payment illegal as an essential part of its sanction, Tank Truck Rentals v. Commissioner, supra note 16.

${ }^{146}$ James v. United States, 366 U.S. 213 (1961) (embezzler taxable on embezzled funds despite the continuing unconditional obligation to repay).

${ }^{147}$ In the paragraph that includes note 133 supra.

${ }^{148}$ I.R.C. $\S 162(c)(2)$.

${ }^{149} I d$.

${ }^{150}$ I.R.C. $§ 161$.

${ }^{151}$ Although it has assumed timing for taking a payment into account to be the basic function of I.R.C. $\S 162$, Congress has been somewhat sloppy in clarifying the point. The Department of the Treasury has had to fill in clarifying details through regulations. For example, I.R.C. $\S 83(\mathrm{~h})$ provides the service recipient a deduction under I.R.C. $\S 162$ when the service provider has an inclusion in income. Nevertheless, few would dispute that the deduction is really shorthand for taking the payment into account, possibly as a 
durationally different from a current deduction, the second change should be denial of the manufacturer 's inclusion of the payment to the temporary service in inventory cost. Denial of a deduction for the ordinary and necessary business expense should translate into an equivalent for durationally more durable property. In this instance the equivalence is denial of inventory inclusion. Nevertheless, Max Sobel is to the contrary and its holding negates the independence of ancillary tax consequences from resolution of the current-capital classification. ${ }^{152}$

The third possible change relates to the income or gain from the sales of the manufactured goods. While illegal sales of property remain taxable events, taxability of the sales of the goods by the temporary service and the manufacturer both may change. As the machine operator's inclusion in income is the value of the manufactured goods received, the temporary service has sold the goods for that amount. ${ }^{153}$ The excess of that amount over the temporary service's adjusted basis in the goods, that is the amount it included in income when it received the goods ${ }^{154}$ is the gain the temporary service realizes and recognizes (or if negative the loss realized and recognized) ${ }^{155}$ Nevertheless,

capital expenditure. Treas. reg. §1.83-6(a)(4) adopts that approach. Similarly, consider I.R.C. §707(c) relating to guaranteed payments by partnerships before Congress amended the statute in 1976.

${ }^{152}$ Max Sobel Wholesale Liquors v. Commissioner, supra note 33. See discussion infra in text commencing with note 161 .

${ }^{153}$ The temporary service's amount realized under 1001(b) is the value of the services and the exchange equivalency doctrine, explained supra in note 135, should compel this outcome.

${ }^{154}$ Treas. reg. $§ 1.61-2(d)(2)(i)$.

${ }^{155}$ I.R.C. $§ 1001(a),(c)$. 
the applicable regulation casts doubt on the outcome as it ties the amount realized into the deduction amount. ${ }^{156}$ As the taxpayer has no deduction, ${ }^{157}$ perhaps its amount realized is zero, thereby generating a loss to the temporary service. But borrowing analysis from the personal world demonstrates that reading the regulation in that manner is wrong. If payment with appreciated property were in the personal world, the taxpayer would not be able to take a deduction. ${ }^{158}$ Under a strict reading of the regulation, payment with appreciated property for services in the personal world never would generate taxable gain to the payer - obviously not an accurate statement of the law. Similarly, the manufacturer's inclusion in gross revenue of the value of the goods should not change, but both the applicable regulation under the foregoing analysis ${ }^{159}$ and Max Sobel $^{160}$ may produce a contrary result.

In Max Sobel Wholesale Liquors v. Commissioner, ${ }^{161}$ the taxpayer, a wholesale liquor distributor, provided liquor to some of its customers in excess of the amount for which they paid state regulated prices. The practice violated California law, such that the taxpayer could not have deducted the value of the excess liquor as a business expense. ${ }^{162}$ However, the taxpayer reduced its closing inventory by the amount of additional liquor

\footnotetext{
${ }^{156}$ Treas. reg. $\$ 1.83-6(\mathrm{~b})$, second sentence.

${ }^{157}$ I.R.C. $\S 162(c)(2)$.

${ }^{158}$ I.R.C. $\S 262$.

${ }^{159} I d$.

${ }^{160}$ Supra note 33. See discussion infra in next paragraph.

${ }^{161}$ Id. The Commissioner acquiesced in Max Sobel at 1982-2 C.B. 2.

${ }^{162} I d$. at 671 citing I.R.C. $\$ 162(\mathrm{c})(2)$.
} 
provided to customers, thereby increasing its cost of goods sold and decreasing its gross income. ${ }^{163}$ The Ninth Circuit, affirming the tax court, ${ }^{164}$ rejected the government's argument that the additional liquor, as illegal payments, could not be part of the cost of goods sold. ${ }^{165}$ Instead, the court emphasized that the tax law does not treat above the line (gross revenue reducers) and below the line (gross income reducers) expenditures identically. ${ }^{166}$ While it did not conclude, as the tax court did, that Congress' failure to include inventory in the disallowance statute was an expression of Congressional intent, ${ }^{167}$ the Ninth Circuit cited the taxpayer favorable, statutory construction rule stated

\footnotetext{
${ }^{163}$ Withdrawal of the additional liquor from inventory decreased closing inventory and increased the taxpayer's cost of goods sold. See explanation of inventory accounting in note 130 supra.

${ }^{164}$ Max Sobel, supra note 33 at 671.

165 The government relied on I.R.C. §162(c)(2), incorporated into the inventory rules in Treas. regs. $§ 1.61$ $3(a)$ and $\S 1.471-3(d)$.

${ }^{166}$ Max Sobel, supra note 33 at 671.

${ }^{167}$ In Max Sobel Wholesale Liquors v. Commissioner, 69 T.C. 477, 484-5 (1977), the tax court addresses I.R.C. §162(c)(2) as follows:
}

We must assume that Congress was aware of the decision of this Court in the Pittsburgh Milk case. At the time that the legislation was enacted, the respondent had acquiesced in that decision. If Congress had intended to overrule the Pittsburgh Milk case, it is only reasonable to expect that the amendment would have been more specific in so doing or that the congressional intent would find expression in the report of the Finance Committee accompanying the bill. No mention of any such intent is made in the report of the Finance Committee accompanying the bill. (citation).

On appeal, the Ninth Circuit correctly elects not to place much store in absence of any expression of Congressional intent in the legislative history. Unless Congress confronted the issue expressly and decided not to include inventory and not to reverse Pittsburgh Milk, silence in the legislative 
in Greyhound Corp. v. United States, ${ }^{168}$ in support of its decision that it should not extend the business expense denial provision to inventory cost. ${ }^{169}$

The government in Max Sobel ${ }^{170}$ did not argue, as this article does, that deduction of ordinary and necessary business expenses is conceptually identical, except for relational duration, to inclusion in inventory. Neither did the government argue, or the case address, the issue of foregone revenue from the excess liquor. Had the taxpayer used the liquor for payment of additional compensation to sales staff or for other purposes, ${ }^{171}$ it most likely would have been deemed to have sold the liquor for the history means little and a negative inference makes little sense. Perhaps the draftsman of the provision simply did not consider the matter. Perhaps political considerations mandated a simple provision, unfettered by multiple appearances or cross-references in the bill. Not until enactment of I.R.C. §263A in 1986, and then only in a 1988 amendment, did Congress seem to confront the more general allowance question. See discussion in Part V infra.

${ }^{168} 495$ F.2d 863, 869 ( $9^{\text {th }}$ Cir. 1974): '[i]n cases of doubt, a taxing statute must be construed most strongly in favor of the taxpayer and against the government. Tax statutes are not to be extended by implication beyond the clear import of the language used.'

${ }^{169}$ Max Sobel, supra note 33 at 672 . Courts continue to cite Max Sobel with approval even when the tax year involved is post-enactment of I.R.C. §263A. United States v. Standard, 96-1 USTC $(\mathrm{CCH}) \llbracket 50,302$ ( $9^{\text {th }}$ Cir. 1996), (unpublished decision involving the tax year 1987 cited with approval but applicable to the facts only insofar as willfulness was concerned in a criminal tax case). Friedman v. Commissioner, 82 TCM 381 (2001) (involving taxable years 1989-90, citing Max Sobel with approval but taxpayer failed to substantiate deduction or reduction of gross revenue).

${ }^{170} \mathrm{Id}$.

${ }^{171}$ Treas. reg. $§ 1.83-6(b)$. See discussion in text accompanying note 133 supra. 
regulated price as state law required. That regulated price should fix fair market value for purposes of compensation paid in property because no other price was lawfully available. ${ }^{172}$ But, by giving the liquor to its vendees, the taxpayer avoided inclusion of the revenue and reduced gross income through the cost of goods. The Ninth Circuit did acknowledge that disallowance of tax benefits for emergency price control violations resembled the disallowance that the government supported for illegal payments, but the court thought the emergency nature of the price controls justified a different outcome in those cases. ${ }^{173}$

The court in Max Sobel finds no material distinction between the case before it and Pittsburgh Milk. ${ }^{174}$ The taxpayer in Pittsburgh Milk ${ }^{175}$ paid rebates to its customers in violation of lawful and state enforced price controls. The government argued that illegality of the rebates should preclude the taxpayer from claiming the rebates as a reduction of its gross revenue. The tax court held, however, that the taxpayer sold the milk for the price its customers paid net of the rebate. ${ }^{176}$ Hence proceeds received net of the rebate constituted the taxpayer's gross revenue. Illegality of the rebate did not alter the tax outcome.

\footnotetext{
${ }^{172}$ I.R.C. $\S 83(a)$.

${ }^{173}$ Max Sobel, supra note 33, at 673.

${ }^{174} I d$. at 672 .

${ }^{175}$ Supra note 33. The Commissioner withdrew non-acquiescence and acquiesced in the decision at 1976-2

C.B. 3.

${ }^{176}$ Id. at 715 .
} 
The tax court's logic is difficult to dispute. The rebate seems no different from the trade discounts to which the court alludes or a sale at below lawful price in open violation of the law. ${ }^{177}$ Perhaps the tax court should have considered ancillary state law consequences of open sale at an illegal, discounted price. Open violation of the law presumably would cause the state to enforce the price requirement against both the buyer and the seller. The state was likely to confiscate the rebate amount with no deduction for the buyer. ${ }^{178}$ And the seller should be taxed on the rebated amount with a non-deductible fine of that amount paid to the state. ${ }^{179}$

The tax court in Pittsburgh Milk acknowledges that there may be instances in which the taxpayer intends the rebate to serve another function. ${ }^{180}$ That reservation highlights a flaw in the court's analysis. While certainly a close question, an unlawful price reduction must be something other than a true price reduction because only the state has authority to reduce the price. ${ }^{181}$ Thus, the rebate must have been something other

${ }^{177}$ Id. at 716. The taxpayer in Pittsburgh Milk sought to disguise the rebates in order to avoid prosecution for violating price controls.

${ }^{178}$ I.R.C. $\$ 162(f)$.

${ }^{179} I d$.

${ }^{180}$ Pitttsburgh Milk, supra note 33 at 716-7.

${ }^{181}$ Compare Wentz v Commissioner, 105 T.C. 1 (1995), in which the taxpayers received a rebate from the selling agent of the full premium on life insurance. The taxpayers sought to treat the rebate as a purchase price reduction. The court held them taxable on the value of the insurance. Since only the insurance company could reduce the price and not the agent, the rebate was a payment to them and not a premium reduction. The agent not involved in the case would have been taxable on his full commission with probably no deduction for the payment to the taxpayers. 
than a price reduction. Perhaps the seller deflected part of the revenue to the buyer.

Redirection of revenue from the taxpayer to another person does not cause the revenue to be any less includable in the taxpayer's income. ${ }^{182}$ Under appropriate circumstances, the taxpayer may have made a deductible or capital payment that would be includable to the recipient. ${ }^{183}$ Albeit in violation of state pricing rules, the taxpayer may have been paying for continued patronage, possibly an expenditure in the nature of goodwill. ${ }^{184}$

\section{Synthesizing Rules to Eliminate Accounting Conflicts: Uniform Capitalization and Transactional Accounting.}

Capitalization and inventory cost determination differ conceptually in their relational durations only, ${ }^{185}$ and not in their operating rules. ${ }^{186}$ Inventory accounting does differ from capital asset accounting in that it may permit taxpayers to take loss in value of

\footnotetext{
${ }^{182}$ Lucas v. Earl, 281 U.S. 111 (1930), establishes the principle that a taxpayer may not deflect income to another as Earl tried unsuccessfully to do in assigning half his income to his spouse.

${ }^{183}$ For example, an accountant may direct a client to pay part of the amount the accountant bills directly to the accountant's employee. Both the employee and the accountant include the amount involved in their respective incomes, and the accountant may be able to deduct the payment as an ordinary and necessary business expense under I.R.C. §162(a)(1).

${ }^{184}$ Compare, Welch v. Helvering, supra note 28.

${ }^{185}$ See text accompanying notes 128-132 supra.

${ }^{186}$ Compare Treas. reg. $\S 1.471-11$, for example, with Idaho Power, supra note 34, at 12. Now I.R.C. §263A governs both capitalization and inventory.
} 
inventory into account currently. ${ }^{187}$ The inventory decisions discussed in the previous part of this article emphasize the distinction between gross revenue and gross income. ${ }^{188}$ Gross revenue less the cost of goods sold is "above the line" and, therefore, free from policy constraints for illegal payments. ${ }^{189}$ Similarly, the excess of the amount realized over the adjusted basis of property is "above the line." ${ }^{190}$ Emphasis on the above/below the line distinction permits taxpayers to capture tax benefits that the expression of public policy in current deduction limitations would deny them for similar expenditures with different relational durations. ${ }^{191}$ As capital expenditures are more like inventory cost than current deduction insofar as relational duration is concerned, the inventory decisions open the door to broad-based capitalization of expenditures that would not be deductible if they were current. ${ }^{192}$ The above the line/below the line distinction, however, seems shortsighted, as it fails to place accounting rules into their tax law context. Accounting rules serve the computation of taxable income but ought not drive it where countervailing tax principles exist. Although courts continue to cite Pittsburgh Milk ${ }^{193}$ with approval, ${ }^{194}$

\footnotetext{
${ }^{187}$ Treas. reg. § 1.471-4 (cost or market, whichever is lower). Compare, however, depreciation on durable business assets that allows taxpayers to take loss in value into account annually. See discussion infra in text accompanying and following note 212 .

${ }^{188}$ Max Sobel, supra note 33 at 671, Pittsburgh Milk, supra note 33, at 715.

${ }^{189}$ Max Sobel, supra note 33 at 671 . By "above the line," the courts refer to computations that produce a net amount to include in gross income, as opposed to "below the line" referring to deductions that reduce gross income.

${ }^{190}$ I.R.C. $\S \S 61(a)(3), 1001(a)$.

${ }^{191}$ I.R.C. $\S 162(c)(2)$.

${ }^{192}$ See discussion in Part III supra commencing with the text accompanying note 111.

${ }^{193}$ Supra note 33.
} 
if the Pittsburgh Milk court had viewed tax categories as interrelated and linked rather than discrete, the outcome in Pittsburgh Milk might have favored the government, as it should.

Accounting rules are part of a tax system, not independent of it, and should adjust to the needs and policies of that system. In Burnet v. Sanford \& Brooks Co. ${ }^{195}$ for example, the Supreme Court held that annual accounting precluded the taxpayer from offsetting the income from a contract with the expenses of performing the contract incurred in earlier years. Several years later, ${ }^{196}$ Congress observed that strict annual accounting was inconsistent with business needs and public policy and relaxed the annual accounting system by permitting taxpayers to carry net operating losses forward (and back) rather than losing the tax benefit of expenses as occurred in Sanford \& Brooks. ${ }^{197}$ Similarly, annual accounting yielded to transactional accounting in order to reopen transactions closed by annual accounting. Important basic tax doctrines including claim of right ${ }^{198}$ and the tax benefit rule ${ }^{199}$ developed judicially in an annual accounting world

${ }^{194}$ Nunn v. Commissioner, 84 T.C.M. 403 (2002), (approving the principle of Pittsburgh Milk on returns and allowances but the taxpayer failed to substantiate the adjustments).

${ }^{195} 282$ U.S. 359 (1931).

${ }^{196}$ Section 211(b) of the Revenue Act of 1939, Pub. No. 155, 53 Stat. 862 (June 29, 1939), added the first net operating loss deduction as section 122 of the Internal Revenue Code of 1939.

${ }^{197}$ I.R.C. $§ 172$.

${ }^{198}$ North American Oil Consolidated v. Burnet, 286 U.S. 417 (1932) (holding that the taxpayer include oil revenues when the district court dissolved a receivership and permitted the taxpayer to receive the payment although an adverse claim remained outstanding). 
to counter-balance some inequities of annual accounting. While adjusting for unfairness that may occur with annual accounting, as in United States v. Lewis, ${ }^{200}$ the doctrines failed to compensate for tax rate differentials from the year of the original inclusion or deduction to the year of transaction reversal. ${ }^{201}$

While courts may not have prevented taxpayers from capturing tax benefits through inventory accounting, ${ }^{202}$ courts have devised doctrine to prevent undeserved tax benefits in other contexts where taxpayers complied with the technical requirements for the benefit. In Knetsch v. United States, ${ }^{203}$ the Supreme Court held a borrowing arrangement involving insurance contracts to be a sham and the interest expense nondeductible, despite technical compliance with the statutory requirements for an interest deduction. ${ }^{204}$ In Estate of Franklin v. Commissioner, ${ }^{205}$ the Ninth Circuit disallowed

${ }^{199}$ Dobson v. Commissioner, 320 U.S. 489 (1943) (affirming the Board of Tax Appeals' decision that a taxpayer who claimed and deducted a loss from sale of shares in an earlier year had to include in income a recovery for violations of securities laws with respect to those shares).

200340 U.S. 490 (1951) (holding that repayment of funds received under a claim of right were deductible in the year of repayment with no adjustment for the smaller amount of tax benefit than the amount of tax detriment suffered earlier).

${ }^{201}$ I.R.C. $\$ 1341$ adjusts in the taxpayer's favor only for tax rate differentials in many claim of right instances but no similar relief is available under the statutory tax benefit rule or I.R.C. $§ 111$.

${ }^{202}$ Max Sobel, supra note 33, Pittsburgh Milk, supra note 33.

203364 U.S. 361 (1960).

${ }^{204}$ Similarly, Goldstein v. Commissioner, 364 F.2d 734 (2d. Cir. 1966) (disregarding a borrowing arrangement designed to average the taxpayer's income over several years with artificial interest deductions). 
depreciation and interest deductions with respect to over-valued real estate the taxpayer financed with non-recourse indebtedness. And in Gregory v. Helvering, ${ }^{206}$ the Supreme Court added a non-statutory limitation to the corporate reorganization provisions of the Code. A transaction must have substance, not just a form, consistent with the function of the tax rules to qualify for the benefit of the rules.

Congress, repeatedly adjusts tax rules, including accounting provisions, to prevent taxpayers from exploiting opportunities to capture tax benefits from technical application of the statutes. In annual accounting contexts, for example, Congress introduced transactional accounting rules into the Code to combat tax planning. A series of provisions matched the deduction and inclusion sides of compensation arrangements by preventing employers from accruing compensation deductions before employees and other service providers might include the amounts in their incomes. ${ }^{207}$ Economic performance and accrual rules examine transactions as a whole and alter the tax timing to

\footnotetext{
${ }^{205} 544$ F.2d $1045\left(9^{\text {th }}\right.$. Cir. 1976).

${ }^{206} 293$ U.S. 465, 469-70 (1935).

${ }^{207}$ For example, I.R.C. $§ 404(a)(5)$ deferring deductions for various employee plan accruals; I.R.C. §83(h) deferring deduction until the service provider must include the item in income; I.R.C. §267(a)(2) matching inclusion and deduction in related party transactions and between tax transparent entities and their owners.
} 
reflect economic reality. ${ }^{208}$ Passive activity loss limitations introduce a general, modified transactional accounting system to a broad range of investment structures. ${ }^{209}$

Other modifications of systemic tax features accommodate taxpayers' need to match income and expenditure better. For example, under the United States' realizationbased income tax system, ${ }^{210}$ taxpayers do not realize gain or loss on their property until they dispose of it. ${ }^{211}$ Yet, depreciation deductions allow taxpayers to take predictable decline in the value of their property into account annually to offset income, even though no disposition of the property occurs. ${ }^{212}$ Contemporary depreciation rules have eliminated the link between decline in value and depreciation allowances in favor of somewhat arbitrary, but certain, allowances. ${ }^{213}$

\footnotetext{
${ }^{208}$ For example, I.R.C. $\S 1272$ et seq. forces economic accrual of original issue discount; I.R.C. $\S 467$ similarly applies to personal property rental arrangements.

${ }^{209}$ I.R.C. $\$ 469$ is only generally transactional, as it groups passive activities and permits losses from one passive activity to offset income from other passive activities.

${ }^{210}$ Eisner v. Macomber, 252 U.S. 189 (1920) (holding narrowly that corporate dividends payable to all shareholders only with additional corporate shares are not taxable and, more broadly, that the $16^{\text {th }}$ Amendment to the U.S. Constitution does not permit taxing unrealized gains). See, generally, Henry Ordower, Revisiting Realization: Accretion Taxation, the Constitution, Macomber, and Mark to Market, 13 VA. TAX REV. 1 (1993) (arguing the continuing constitutional basis for the realization requirement).

${ }^{211}$ I.R.C. $\S \S 1001,165$.

${ }^{212}$ I.R.C. $\S 167$.

${ }^{213}$ I.R.C. $\S 168$.
} 
The uniform capitalization rules ${ }^{214}$ fit within the umbrella of transactional accounting rules. Uniform capitalization acknowledges historical tax inadequacies in identifying accurately relationships that always existed within the tax world. The Supreme Court had confirmed that the underlying relationships were present in Idaho Power $^{215}$ and INDOPCO. ${ }^{216}$ Idaho Power established the foundations of uniform capitalization for trade or business assets by recognizing that depreciation allowances on equipment that a taxpayer used to construct power plants for its business operations were conceptually indistinguishable from bricks and mortar. ${ }^{217}$ The Court reconciled the depreciation with the "amount paid out" requirement of the capitalization statute ${ }^{218}$ by observing: "[d]epreciation is an accounting device which recognizes that the physical consumption of a capital asset is a true cost, since the asset is being depleted." ${ }^{219}$ And further "depreciation is simply the means of allocating the payment [for the equipment] over the various accounting periods affected." 220

The Supreme Court in INDOPCO rejected a narrow, separate asset test for capitalization of expenditures. ${ }^{221}$ The Court observed that: "Lincoln Savings stands for

\footnotetext{
${ }^{214}$ I.R.C. $\$ 263$ A.

${ }^{215}$ Supra note 34.

${ }^{216}$ Supra note 35.

${ }^{217}$ Supra note 34 at $16-17$.

${ }^{218}$ I.R.C. $\$ 263(\mathrm{a})(1)$.

${ }^{219}$ Idaho Power, supra note 34 at 10.

${ }^{220}$ Idaho Power, supra note 34 at 16.

${ }^{221}$ INDOPCO, supra note 35 , at 86.
} 
the simple proposition that a taxpayer's expenditure that 'serves to create or enhance ... a separate and distinct' asset should be capitalized...."222 Commissioner v. Lincoln Savings $\&$ Loan Association $^{223}$ to which the Court refers involved fees that the Federal Savings and Loan Insurance Corporation imposed to create a secondary reserve for each insured institution and that created a separate asset for the taxpayer and were thus capital expenditures. Rather than a separate asset test, the Supreme Court opts for an expenditure duration test -- relational duration as this article expresses the concept - in order to separate ordinary and necessary from capital expenditures:

a taxpayer's realization of benefits beyond the year in which the expenditure is incurred is undeniably important in determining whether the appropriate tax treatment is immediate deduction or capitalization. ${ }^{224}$

While the Court does not state the test as expressly as one might wish, INDOPCO settles the issue of duration. So long as the expenditure, in this instance investment banking and legal fees incurred in restructuring the corporation as a wholly owned subsidiary rather than a separate public corporation, provides a benefit beyond the close of the taxable year, the expenditure is capital not ordinary. ${ }^{225}$

${ }^{222} I d$.

${ }^{223} 403$ U.S. 345, 354 (1971).

${ }^{224}$ INDOPCO, supra note 35 , at 87.

${ }^{225} I d$. But see Treas. reg. $§ 1.263(\mathrm{a})-4(\mathrm{~b})(1)(\mathrm{iii})$ that restores the separate and distinct asset test the INDOPCO Court rejected, supra text accompanying note 223. And see note 105 supra for discussion of the regulation project under I.R.C. $\$ 263$ and INDOPCO. 
Important to both INDOPCO ${ }^{226}$ and Idaho Power $^{227}$ is the function of section 161 of the Code. ${ }^{228}$ In both decisions, the Supreme Court views section 161 as a gatekeeper. Expenditures flowing through any deduction provision either move to a taxable income computation statute $^{229}$ or section 161 redirects them to non-deductibility rules ${ }^{230}$ despite the language that expressly provides for deduction. ${ }^{231}$ Where capitalization is involved, redirection is a function of relational duration of the expenditure. Since inventory and capital expenditures follow substantially identical capitalization or absorption rules, section 161 ought to redirect for both types of expenditures. Section 161 operates only after determination that the taxpayer may take the expenditure into account, so that

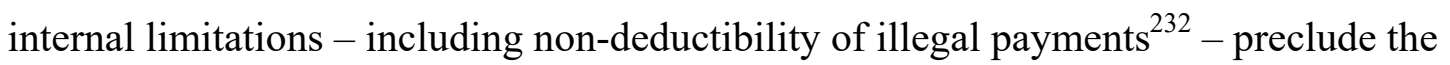
taxpayer from taking the expenditure into account and, accordingly, should preclude the

\footnotetext{
${ }^{226} I d$. at $84:$ :[d]eductions are specifically enumerated and thus are subject to disallowance in favor of capitalization."

${ }^{227}$ Supra note 34 at 17: [t]he clear import of $\S 161$ is that, with stated exceptions ..., an expenditure incurred in acquiring capital assets must be capitalized even when the expenditure otherwise might be deemed deductible under Part VI."

${ }^{228}$ See discussion supra in text accompanying and following note 41 .

${ }^{229}$ I.R.C. $\S 62$ or $\S 63$.

${ }^{230}$ Part IX of subchapter B, I.R.C. $\$ 262$ et seq.

${ }^{231}$ Both I.R.C. $\$ 162$ (a) and I.R.C. $\$ 167$ (a) use the language: [t]here shall be allowed as a ... deduction,” even though capitalization limits both statutes.

${ }^{232}$ I.R.C. $§ 162(c)(2)$.
} 
taxpayer from capitalizing the expenditure. The tax court in Pittsburgh Milk ${ }^{233}$ and the Ninth Circuit in Max Sobel ${ }^{234}$ missed that statutory relationship.

In enacting the uniform capitalization rules in $1986,{ }^{235}$ Congress made the connection between inventory accounting and capitalization unambiguous by applying the same cost absorption rules to both. ${ }^{236}$ Following enactment of uniform capitalization, the gatekeeper provision ${ }^{237}$ expressly applied to inventory as well as other capitalization items. $^{238}$ In 1988, Congress added to the uniform capitalization rule: "[a]ny cost which (but for this subsection) could not be taken into account in computing taxable income for any taxable year shall not be treated as a cost described in this paragraph." ${ }^{, 239}$ The additional sentence further clarified that taxpayers first must determine whether or not they may take an expenditure into account before capitalizing it. The uniform capitalization rule, as so clarified, now seems to preclude inclusion of illegal payments in inventory cost or property, ${ }^{240}$ but courts have not addressed the issues as yet. If that interpretation of the function of the added sentence is correct, limitation of the gatekeeper

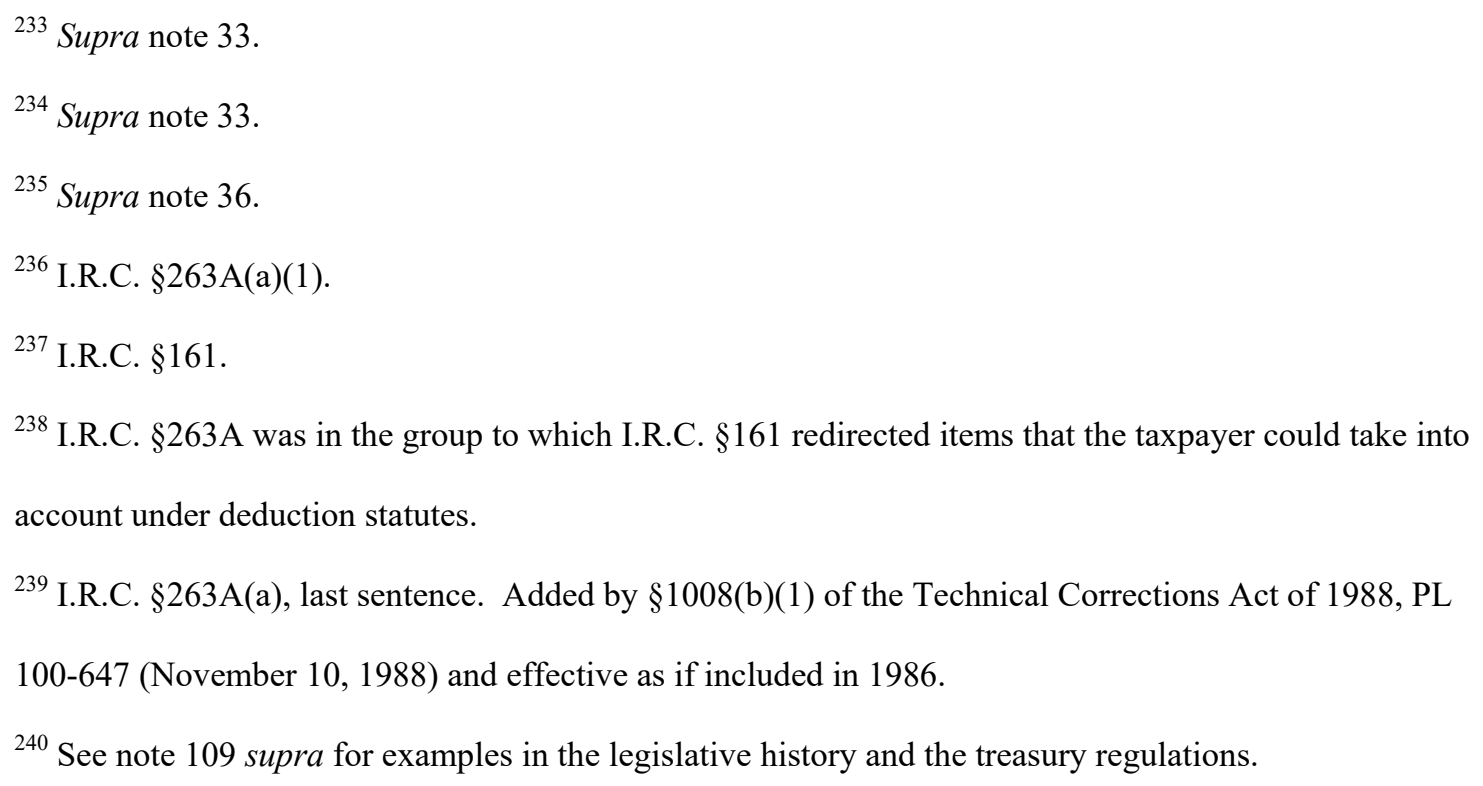


function of section 161 only to items that the taxpayer otherwise may take into account would be consistent with uniform capitalization. Moreover, the legislative history indicates that capitalization of personal expenditures to income-producing property is impermissible, ${ }^{241}$ contrary to the holding in the Gilmore remand. ${ }^{242}$

\section{Conclusion}

This article has argued that taxpayers must assign their expenditures to their personal world or their income-producing world or, in the case of expenditures that function partly in one world and partly in the other, allocate such mixed expenditures between the worlds. Expenditures neither jump from the income producing world to the personal world nor conversely. Once assigned to a world, the expenditure remains in that world and the taxpayer determines whether or not she may take the expenditure into account. If the taxpayer may take the expenditure into account, she must determine the expenditure's relational duration within the world to which it is attributable. Relational duration establishes whether the taxpayer consumes the expenditure currently and deducts it if in the income-producing world or capitalizes it to other property in either world. Property, including its capitalized expenditures, a taxpayer freely may shift from one world to the other and back. Current expenditures in the personal world are not deductible generally and are of no further tax value.

\footnotetext{
${ }^{241} I d$.

${ }^{242}$ Gilmore v. U.S., supra note 1. See discussion in text accompanying and following note 9 supra.
} 
Inventory accounting and capital expenditure accounting are qualitatively indistinguishable. Despite the line of decisions commencing with Pittsburgh Milk ${ }^{243}$ to the contrary, the gross revenue - gross income distinction ought not generate a tax benefit as it does in that line of decisions. Only relational duration, and not limitations on taking expenditures into account, separates inventory expenditures (and capital expenditures) from ordinary and necessary expenditures. That determination of the cost of goods sold for inventory accounting historically appeared in the Code's accounting rules, rather than the capitalization rules, neither alters the equivalence of inventory and capitalization generally nor supports handling inventory absorption differently from ordinary expenditures in any manner other than duration. The uniform capitalization rules of section 263A of the Code, as applied through the section 161 gatekeeper provision, confirm this tax characteristic for both inventory and non-inventory property. Section 263A should preclude any further taxpayer favorable outcomes in the Pittsburgh Milklike cases because the statute expressly requires that a taxpayer be able to take an expenditure into account before permitting inclusion of the expenditure in inventory cost.

${ }^{243}$ Supra note 33. 